УДК 636.087 .7

doi: 10.36359/scivp.2021-22-1.16

\title{
ОЦІНКА БЕЗПЕЧНОСТІ КОРМОВОЇ ДОБАВКИ ДЛЯ КУРЧАТ-БРОЙЛЕРІВ
}

\author{
Т. Р. Левицький, канд. с.-г. наук, \\ Г. Й. Бойко, старший науковий співробітник, \\ О. М. Вільха, науковий співробітник, \\ Г. Ю. Неділька, науковий співробітник, \\ Г. Ю. Федор, науковий співробітник
}

Державний науково-дослідний контрольний інститут ветеринарних препаратів

та кормових добавок

вул. Донецька, 11, м. Львів, 79019, Україна

taraslev@i.ua

\begin{abstract}
Проведено вивчення безпечності застосування кормової добавки Ліаформ для цільового виду - курчат-бройлерів.

Ліаформ являє собою рідину жовтуватого кольору із специфічним запахом. У склад кормової добавки входить молочна кислота, мурашина кислота, натрію форміат, пропіонова кислота та вода. Враховуючи склад добавки, ії можна віднести до двох функиіональних груп: консерванти - речовини або мікроорганізми, які захищають корм від пошкодження мікроорганізмами або їх метаболітами, регулятори кислотності - речовини, які регулюють рівень рН кормів.

Для проведення досліджень було сформовано за принципом аналогів 3 групи курчатбройлерів по 15 голів (контрольну та 2 дослідних) 3 8-денного віку. Годівлю курчат контрольної групи здійснювали стандартним повнораціонним комбікормом. Годівлю курчат першої дослідної групи здійснювали стандартним повнораціонним комбікормом, в який вносили кормову добавку Ліаформ з розрахунку 2 г/кг, годівлю курчат другої дослідної групи здійснювали стандартним повнорачіонним комбікормом, в який вносили кормову добавку Ліаформ в 10-кратній рекомендованій дозі з розрахунку 20 г/кг. В процесі досліду контролювали загальний стан птиці, збереженість птиці, зоотехнічні та гематологічні показники.
\end{abstract}

Встановлено, що досліджувана кормова добавка в 10-кратній рекомендованій дозі не має негативного виливу на продуктивність, ріст та розвиток курчат-бройлерів, засвоєння кормів. У результаті застосування кормової добавки Ліаформ в 10-кратній рекомендованій дозі, жива маси курчат-бройлерів дослідної групи була вищою, у порівнянні з контролем та нижчою, у порівнянні з рекомендованою дозою. Застосування кормової добавки в 10-кратній дозі не мало негативного впливу на гематологічні показники та рівень білка в сироватиі крові, не спричиняло негативної дії на стан внутрішніх органів.

Ключові слова: КОРМОВА ДОБАВКА, ЛІАФОРМ, МОЛОЧНА КИСЛОТА, МУРАШИНА КИСЛОТА, НАТРІЮ ФОРМІАТ, ПРОПІОНОВА КИСЛОТА, БЕЗПЕКА ВИКОРИСТАННЯ. 


\title{
ASSESSMENT OF FEED SUPPLEMENT SAFETY FOR CHICKEN BROILERS
}

\author{
T. R. Levytskyy, H. I. Boiko, O. M. Vilkha, H. Ju. Nedilka, H. Ju. Fedor
}
State Scientific-Research Control Institute of Veterinary Medicinal Products and Feed Additives, 11, Donetska str., Lviv, 79019, Ukraine
taraslev@i.ua chickens.

A study of the safety of the use of feed additive Liaform for the target species - broiler

Liaform is a yellowish liquid with a specific odor. The feed additive contains lactic acid, formic acid, sodium formate, propionic acid and water. Given the composition of the additive, it can be attributed to two functional groups: preservatives - substances or microorganisms that protect feed from damage by microorganisms or their metabolites, acidity regulators - substances that regulate the $\mathrm{pH}$ of feed.

For the study was formed on the principle of analogues of 3 groups of broiler chickens of 15 heads (control and 2 experimental) from 8 days of age. Feeding of chickens of the control group was carried out by standard complete feed. Feeding of chickens of the first experimental group was carried out with standard complete feed, in which the feed additive Liaform was added at the rate of $2 \mathrm{~g} / \mathrm{kg}$, feeding of chickens of the second experimental group was carried out with standard complete feed, in which feed additive Liaform was applied in 10 times the recommended dose of $20 \mathrm{~g} / \mathrm{kg}$. During the experiment, the general condition of the bird, the safety of the bird, zootechnical and hematological parameters were monitored.

It was found that the studied feed additive in 10 times the recommended dose does not have a negative impact on productivity, growth and development of broiler chickens, feed absorption. As a result of the use of Liaform feed additive in 10 times the recommended dose, the live weight of broiler chickens in the experimental group was higher compared to the control and lower compared to the recommended dose. The use of a feed additive in 10 times the dose did not have a negative effect on hematological parameters and serum protein levels, did not cause a negative effect on the condition of internal organs.

Keywords: FEED ADDITIVE, LIAFORM, LACTIC ACID, FORMIC ACID, SODIUM FORMIATE, PROPIONIC ACID, SAFETY OF USE

Досягнення високої продуктивності сільськогосподарських тварин та птиці неможливе без забезпечення повноцінними та безпечними кормами. Для виробництва повноцінних повнораціонних кормів необхідно застосовувати різноманітні кормові добавки. Кормові добавки це речовини, мікроорганізми або суміші, інші ніж кормовий матеріал або премікси, які спеціально додаються до корму або води з метою виконання однієї чи декількох з таких функцій: задоволення поживних потреб тварин, забезпечення сприятливого впливу на характеристики кормів, продуктів тваринного походження, екологічні наслідки тваринницької діяльності, продуктивність та благополуччя тварин, зокрема шляхом впливу на шлунковокишкову флору та засвоюваність кормів чи колір декоративних рибок та птахів, здійснення кокцидіостатичної чи гістомоностатичної дії. Кормові добавки поділяються на п’ять категорій. У межах відповідної категорії кормова добавка може бути віднесена до однієї або декількох функціональних груп (Zakon Ukrayiny «Pro bezpeku ta gigiyenu kormiv», 2018).

Технологічні кормові добавки із функціональних груп консерванти та регулятори кислотності на даному етапі відіграють важливу роль в забезпеченні ефективної повноцінної та безпечної годівлі птиці, особливо молодняку птиці та курчат-бройлерів. Слід зазначити, що у молодняку птиці секреція соляної кислоти в шлунку і її активність є низькою. В результаті 
такої фізіологічної реакції виділяється недостатньо кислоти для того, щоб набухала кормова маса і повністю нейтралізувалися iii лужні властивості (Podobed, 2013).

Крім того, перехід від антибіотиків до альтернативних препаратів почався в Свропі і сьогодні має широке поширення в усьому світі. Наукові дослідження активно проводяться в цьому напрямку. Найбільш прогресивною альтернативою антибіотиків можна назвати кормові добавки - регулятори кислотності, що представляють собою суміші органічних кислот і їх солей (Lyukshtadt et al., 2013).

Використовувати кормову добавку для виробництва корму та/або здійснювати іiі обіг, можна лише за умови що така кормова добавка зареєстрована в Україні. Важливою умовою реєстрації в Україні є вивчення ефективності та безпечності кормової добавки. Проведеними дослідженнями встановлено позитивний вплив кормової добавки Ліаформ на продуктивність курчат-бройлерів (Levytskyi, 2020).

Згідно з вимогами Європейського Союзу (COMMISSION REGULATION (EC) № 429, 2008) та вітчизняних рекомендацій (Kocyumbas et al., 2013), вивчення безпечності технологічних добавок повинно проводитися не тільки на лабораторних, а й на цільових видах тварин. Питання безпечності застосування кормової добавки Ліаформ на цільових тваринах залишається відкритим.

Тому, метою нашої роботи було вивчення безпечності застосування кормової добавки Ліаформ на цільових видах тварин - курчатах-бройлерах.

Матеріали і методи. Дослідження проводили на базі лабораторії контролю кормових добавок та преміксів та клініки Державного науково-дослідного контрольного інституту ветеринарних препаратів та кормових добавок. У дослідженнях було використано кормову добавку Ліаформ, виробництва ТОВ «САНФОРТ-П», Україна. Ліаформ являє собою рідину жовтуватого кольору із специфічним запахом. У склад кормової добавки входить молочна кислота, мурашина кислота, натрію форміат, пропіонова кислота та вода. Згідно зі статтею 16, кормову добавку Ліаформ слід відносити до категорії технологічних добавки. Враховуючи склад добавки, ії можна віднести до двох функціональних груп: консерванти - речовини або мікроорганізми, які захищають корм від пошкодження мікроорганізмами або їх метаболітами, регулятори кислотності - речовини, які регулюють рівень $\mathrm{pH}$ кормів (Zakon Ukrayiny «Pro bezpeku ta gigiyenu kormiv», 2018).

Виходячи із мети дослідження, нами було проведено вивчення безпечності кормової добавки для цільових видів тварин - курчат-бройлерів, у відповідності із методичними рекомендаціями (Kocyumbas et al., 2011; Levytskyi, 2013).

Згідно з рекомендаціями (Levytskyi, 2013) для проведення досліджень було сформовано 3 групи птиці:

а) контрольна група, яка не отримує кормової добавки;

б) перша дослідна група, яка отримує максимально рекомендовану дозу кормової добавки;

в) друга дослідна група, яка отримує дозу, що багаторазово перевищує максимально рекомендовану дозу.

Дослідження були проведені на курчатах-бройлерах кросу Ross 308. Було сформовано за принципом аналогів 3 групи по 15 голів у кожній, з 8-добового віку.

У приміщенні, де проводилися дослідження, дотримувалися стандартні параметри мікроклімату і утримання птиці, згідно з зоотехнічними та ветеринарними вимогами по вирощуванню бройлерів кросу Ross 308.

Годівля птиці дослідних та контрольної груп здійснювалася згідно з Рекомендаціями по вирощуванню бройлерного поголів'я бройлерного класу Ross 308 з врахування віку птиці.

Птиця контрольної групи отримувала повнораціонний комбікорм, у відповідності до віку птиці. Птиця першої дослідної групи отримувала повнораціонний комбікорм 3 додаванням кормової добавки у рекомендованій дозі 2 г/кг корму. Птиця другої дослідної 
групи отримувала повнораціонний комбікорм 3 додаванням кормової добавки у 10-кратній рекомендованій дозі - 20 г/кг корму. Тривалість досліду становила 35 днів.

В процесі досліду контролювалися такі показники: загальний стан птиці, збереженість птиці, зоотехнічні та гематологічні показники.

Лабораторні дослідження проводилися в лабораторії контролю кормових добавок та преміксів і лабораторії клініко-біологічних досліджень ДНДКІ ветпрепаратів та кормових добавок.

Для оцінки загального стану організму та характеристики змін основних параметрів організму було підібрано ряд лабораторних тестів, що відповідали основним клінічним вимогам. Морфо-функціональний стан організму птиці встановлювали за морфологічними, імунологічними та біохімічними показниками крові, які визначали згідно із загальноприйнятими методиками (Vlizlo et al., 2012; Koсуumbas et al., 2014].

Для морфологічних досліджень використовували стабілізовану гепарином кров, а для біохімічних досліджень - сироватку крові.

У стабілізованій крові визначали такі показники: вміст гемоглобіну, число еритроцитів, лейкоцитів, гематокрит. У сироватці крові визначали: загальний білок - рефрактометричним методом.

Отримані результати обробляли статистично, оцінюючи вірогідність різниці показників ( $<0,05$,) за критерієм Стьюдента

Результати й обговорення. Загальний стан птиці обох дослідних та контрольної груп протягом досліду був задовільний. Захворювань та загибелі птиці протягом досліду не відмічали. Щоденний огляд птиці дослідних та контрольної груп показав, що клінічний стан курчат дослідної та контрольної групи був задовільний, апетит був збережений протягом усього досліду. Відхилень за цими показниками у курчат другої дослідної групи не встановлено. Зовнішній вигляд був задовільний, птиця була рухлива.

Враховуючи те, що динаміка маси тіла птиці є одним з найважливіших інтегральних показників стану здоров'я птиці, протягом досліду проводилося зважування птиці. Жива маса птиці протягом досліду наведена в таблиці 1.

Таблиия 1

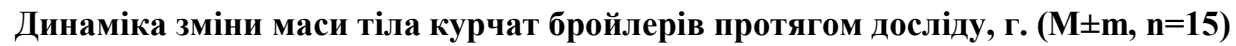

\begin{tabular}{|c|c|c|c|}
\hline Вік птиці, днів & Контрольна група & 1 дослідна група & 2 дослідна група \\
\hline 8 & $263 \pm 21$ & $268 \pm 29$ & $260 \pm 25$ \\
\hline 42 & $2602 \pm 89$ & $2709 \pm 84$ & $2665 \pm 74$ \\
\hline
\end{tabular}

Викладені в таблиці 1 дані показують, що жива маса курчат-бройлерів 1 дослідної групи, яка отримувала кормову добавку в рекомендованій дозі, в кінці досліду становила 2709 г, жива маса курчат 2 дослідної групи - 2665 г і була вищою відповідно на 107 г та 63 г у порівнянні з живою масою курчат-бройлерів дослідної групи. Показники живої маси курчатбройлерів контрольної та дослідних груп відповідали нормативним показникам. Це свідчить про те що, внесення кормової добавки Ліаформ у рекомендованій дозі та у 10-ти кратній рекомендованій дозі не викликало негативного впливу на масу курчат бройлерів протягом досліду та сприяло підвищенню живої маси курчат-бройлерів у порівнянні 3 контролем на 4,1 \% у першій дослідній групі та на 2,42\% у другій дослідній групі.

Середньодобові прирости живої маси бройлерів наведені у таблиці 2.

Таблиия 2

Прирости маси курчат бройлерів протягом досліду

\begin{tabular}{|c|c|c|}
\hline Групи птиці & Приріст за період досліду, г & Середньодобовий приріст за період досліду, г \\
\hline Контрольна & 2339 & 66,8 \\
\hline 1 дослідна & 2441 & 69,7 \\
\hline 2 дослідна & 2405 & 68,7 \\
\hline
\end{tabular}


Дані таблиці 2 свідчать, що внесення у раціон курчат-бройлерів кормової добавки забезпечувало підвищення загального приросту живої маси у курчат першої та другої дослідної групи. Так, за період досліду у птиці першої дослідної групи він був на 102 г вищим, у порівнянні з контролем, у птиці другої дослідної групи - на 66 г. Середньодобові прирости за період досліджень у контрольній групі становили 68,8 г, у першій дослідній групі - 69,7 г, другій дослідній групі - 68,7. Це свідчить, що застосування кормової добавки у складі повнораціонного корму в рекомендованій дозі сприяло підвищення середньодобових приростів на 4,3 \%, у порівнянні з контролем, без внесення кормової добавки, при внесенні 10кратної рекомендованої дози цей показник становив $2,8 \%$.

Отже, дані таблиць 1 і 2 свідчать, що застосування кормової добавки Ліаформ в рекомендованій дозі позитивно впливає на ріст та розвиток курчат-бройлерів. Негативного впливу на ріст та розвиток курчат-бройлерів 10-кратної рекомендованої дози не встановлено.

Окрім динаміки маси тіла птиці, важливим інтегральним показником ефективності та безпечності застосування кормових добавок є показники конверсії корму. Показники конверсії корму при вивченні безпечності кормової добавки Ліаформ для цільових видів тварин наведені в таблиці 3.

Таблиця 3

Показники конверсії корму в кінці досліду

\begin{tabular}{|c|c|c|c|}
\hline Показники & Контроль & 1 дослідна & 2 дослідна \\
\hline Споживання корму за період досліду, г & 4574 & 4574 & 4574 \\
\hline Приріст курчат-бройлерів за період досліду, г & 2339 & 2441 & 2405 \\
\hline Конверсія корму, кг & 1,96 & 1,87 & 1,90 \\
\hline
\end{tabular}

Як випливає 3 даних таблиці 3, застосування кормової добавки в рекомендованій дозі та десятикратній рекомендованій дозі сприяло підвищенню конверсії корму. Так, затрати корму на 1 кг приросту у контрольній групі становило 1,96 кг, тоді як у першій дослідній 1,87 кг корму, у другій дослідній - 1,90 кг. Слід зазначити що, у курчат другої дослідної групи при внесенні 10-кратної рекомендованої дози кормової добавки, показник конверсії корму був нижчим, ніж у курчат першої дослідної групи, хоча і перевищував цей показник контрольної групи.

Причиною підвищення засвоюваності поживних речовин при застосуванні регуляторів кислотності (підкислювачів) є їх вплив на збільшення всмоктувальної поверхні кишечнику, що сприяє швидкій абсорбції поживних речовин слизовою оболонкою кишечника (Lyukshtadt et al., 2013).

Також встановлено, що використання регуляторів кислотності підсилює процес нейтралізації кислото-зв'язувальної здатності кормових компонентів раціону, з найменшими для організму витратами знижує $\mathrm{pH}$ шлункового вмісту, створює оптимальний рівень кислотності для перетравлення, всмоктування поживних речовин в нижніх відділах шлунковокишкового тракту та підвищує продуктивність курчат-бройлерів (Podobed, 2013; Hamko, 2015].

В кінці досліду було проведено дослідження гематологічних та біохімічних показників крові. Результати гематологічних досліджень наведено в таблиці 4.

Наведені дані свідчать, що застосування кормової добавки в рекомендованій та 10кратній рекомендованій дозі не спричиняло суттєвої різниці за досліджуваними показниками між контрольною та дослідними групами, за винятком вмісту гемоглобіну. Так, встановлено, що вміст гемоглобіну у крові курчат контрольної групи становив 83,8 г/л, у крові курчат першої дослідної групи 90,1 г/л. що є на 7,5 \% вищим, у порівнянні з контролем, у крові курчат другої дослідної групи 85,4 г/л.

Отже, 10-кратна рекомендована доза кормової добавки не має негативного впливу на гематологічні показники курчат-бройлерів. 
Гематологічні показники курей-бройлерів за випробування безпечності кормової добавки Ліаформ $(\mathbf{M} \pm \mathbf{m}, \mathbf{n}=\mathbf{5})$

\begin{tabular}{|c|c|c|}
\hline Показники & Групи & Значення \\
\hline \multirow{3}{*}{ Еритроцити, Т/л } & Контрольна & $2,3 \pm 0,09$ \\
\cline { 2 - 3 } & 1 дослідна & $2,4 \pm 0,14$ \\
\cline { 2 - 3 } & 2 дослідна & $2,4 \pm 0,16$ \\
\hline \multirow{3}{*}{ Гемоглобін, г/л } & Контрольна & $83,8 \pm 2,8$ \\
\cline { 2 - 3 } & 1 дослідна & $80,1 \pm 3,0 *$ \\
\cline { 2 - 3 } & 2 дослідна & $27,4 \pm 3,1$ \\
\hline \multirow{2}{*}{ Гематокрит,\% } & Контрольна & $28,7 \pm 1,7$ \\
\cline { 2 - 3 } & 1 дослідна & $28,1 \pm 1,2$ \\
\cline { 2 - 3 } & 2 дослідна & $25,9 \pm 1,8$ \\
\hline \multirow{2}{*}{ Лейкоцити, Г/л } & Контрольна & $25,1 \pm 1,1$ \\
\cline { 2 - 3 } & 1 дослідна & $26,0 \pm 1,2$ \\
\cline { 2 - 3 }
\end{tabular}

Примітка: різниця статистично вірогідна порівняно до контролю: * $-\mathrm{p} \leq 0,05$

Показники білкового обміну курчат-бройлерів за випробування ефективності застосування кормової добавки Ліаформ наведені в таблиці 5.

Таблиця 5

Вміст загального білка за випробування безпечності кормової добавки Ліаформ, $(\mathrm{M} \pm \mathrm{m}, \mathbf{n}=5)$

\begin{tabular}{|c|c|c|}
\hline Показники & Групи & Значення \\
\hline \multirow{3}{*}{ Загальний білок, г/л } & Контроль & $33,2 \pm 1,2$ \\
\cline { 2 - 3 } & 1 дослідна & $36,1 \pm 1,6^{*}$ \\
\cline { 2 - 3 } & 2 дослідна & $35,2 \pm 1,7$ \\
\hline
\end{tabular}

Примітка: різниця статистично вірогідна порівняно до контролю: * $-\mathrm{p} \leq 0,05$

При аналізі показників білкового обміну птиці відмічалася тенденція до підвищення вмісту загального білка в сироватці крові курчат дослідної групи. Зокрема, у птиці контрольної групи цей показник становив,33,2 г/л, у птиці першої дослідної групи - 36,1 г/л, у птиці другої дослідної групи - 34,9 г/л. Введення кормової добавки у 10-кратній дозі не мало негативного впливу на рівень білку.

Підвищення рівня білка у курчат дослідних груп очевидно пояснюється тим, що кормова добавка знижує значення $\mathrm{pH}$, створюючи оптимальні умови для перетравлення білків і значно знижують навантаження на шлунок. Вищий рівень кислотності в шлунку сприяє більшому виділенню соку та ферментів підшлункової залози (Polishchuk, 2010).

При вивченні маси внутрішніх органів, зокрема, печінки, серця, нирок, легень та м'язового шлунка вірогідної різниці між контрольною та дослідною групами не спостерігали.

При патологоанатомічному розтині курчат-бройлерів в кінці досліду, видимих патологічних змін внутрішніх органів не виявляли У курчат дослідних та контрольної груп не спостерігали змін органів травного тракту, крововиливів, слизові оболонки цілісні, без нашарувань. Печінка темно-коричневого кольору, гладенька, без крововиливів та інших ушкоджень. Жовчний міхур округлої форми, без ушкоджень, крововиливів, помірно наповнений, вмістиме темно-зеленого кольору. Нирки без крововиливів. Селезінка видовженої форми, червоно-коричневого кольору, без ушкоджень, краї рівні. Серце конічної форми, без крововиливів та ушкоджень. 
Наведені дані свідчать, що внесення в склад корму 10-кратної дози кормової добавки не спричиняє негативної дії на стан внутрішніх органів. Інші дослідники підтверджують відсутність негативного впливу додавання органічних кислот до раціону на масу та вихід внутрішніх органів (Antongiovanni et al. 2007; Seifi et al., 2015).

\section{В И С Н О В К И}

1. В результаті проведених досліджень встановлено, що кормова добавка Ліаформ при внесенні в корми для курчат-бройлерів у 10-кратній рекомендованій дозі не має негативного впливу на ріст та розвиток, гематологічні показники та стан внутрішніх органів курчат бройлерів.

2. Отже, кормова добавка Ліаформ має достатній запас міцності та є безпечною для цільових видів - курчат бройлерів у десятикратній рекомендованій дозі.

Перспективи досліджень. Проведення випробувань безпечності застосування кормової добавки Ліаформ на інших видах сільськогосподарської птиці та тварин.

\section{References}

Antongiovanni, M., Buccioni, A., Petacchi, F. et al. (2007). Butyric acid glycerides in the diet of broiler chickens: Effects on gut histology and carcass. Italian Journal of Animal Science. 6. 1925.

Commission Regulation (EC) № 429/2008 of 25 April 2008 on detailed rules for the implementation of Regulation (EC) No 1831/2003 of the European Parliament and of the Council as regards the preparation and the presentation of applications and the assessment and the authorisation of feed additives (Official Journal of the European Union L 133, 22.5.2008. 60).

Hamko L.N. \& Tarynskaia T.A. (2015). Vlyianye podkyslytelei na produktyvnost y sokhrannost tsypliat-broilerov. Ptytsevodstvo. 2. 34-36. [in Russian].

Kocyumbas, I.Ya., Levytskyi, T.R., Ryvak, H.P., Shapovalov, S.O. et al. (2011). Otsinka bezpechnosti kormovykh dobavok. Zahalni pidkhody (Metodychni rekomendatsii) Derzhavnyi naukovo-doslidnyi kontrolnyi instytut veterynarnykh preparativ ta kormovykh dobavok, Lviv. 21. [in Ukrainian].

Kocyumbas, I.Ya., Bisyuk, I.Yu., Gorzheyev, V.M., Malyk, O.G. et al. (2013). Klinichni doslidzhennya veterynarnykh preparativ ta kormovykh dobavok. Lviv, 252. [in Ukrainian].

Kocyumbas, I.Ya., Zhyla, M.I., Piatnychko, O.M. et al. Za red. I. Ya. Kotsiumbasa (2014). Imunotoksykolohichnyi kontrol veterynarnykh preparativ ta kormovykh dobavok: Metodychni rekomendatsii. Lviv. 116. [in Ukrainian].

Levytskyi, T.R. (2013). Zahalni pidkhody do otsinky bezpechnosti kormovykh dobavok //Naukovo-tekhnichnyi biuleten Instytutu biolohii tvaryn i DNDKI vetpreparativ ta kormovykh dobavok. Lviv. 14. 3, 4. 301-308. [in Ukrainian].

Levytskyi, T.R. (2020). Otsinka efektyvnosti zastosuvannia kormovoi dobavky na kurchatakh-broilerakh. Naukovo-tekhnichnyi biuleten Instytutu biolohii tvaryn i DNDKI vetpreparativ ta kormovykh dobavok. Lviv-2020. 21. 2. 90-96. [in Ukrainian].

Lyukshtadt K. Mellor, S., Landshaft, M. Podkislitel v kormlenii brojlerov: ustojchivyj effekta

na produktivnost. Available at: http://webpticeprom.ru/ru/articles-
birdseed.html?pageID=1362981970. (Accessed 11.03.2013) [in Russian].

Podobed, L.I. (2013). Rol podkislitelej v povyshenii produktivnosti/ Kombikorma. 10. 73-76. [in Russian].

Polishchuk, A.A. \& Bulavkina, T.P. (2010). Suchasni kormovi dobavky v hodivli tvaryn ta ptytsi. Visnyk Poltavskoi derzhavnoi ahrarnoi akademii 2. 63-66. [in Ukrainian]. 
Seifi, S., Sayrafi, R., Khoshbakht, R., Gilani, A. (2015). Effects of dietary acetic acid on intestinal microbiota, serum components, internal organs and performance of broilers. Global Journal of Animal Scientific Research. 3 (2). 536-543.

Vlizlo, V.V., Fedoruk, R. S., Ratych, I. B. et al. za red. V. V. Vlizla. (2012). Laboratorni metody doslidzhennia u biolohii, tvarynnytstvi ta veterynarnii medytsyni: dovidnyk. Lviv: Spolom, 764. [in Ukrainian].

Zakon Ukrayiny «Pro bezpeku ta gigiyenu kormiv», Golos Ukrayiny. 12, 19.01.2018. [in Ukrainian]. 